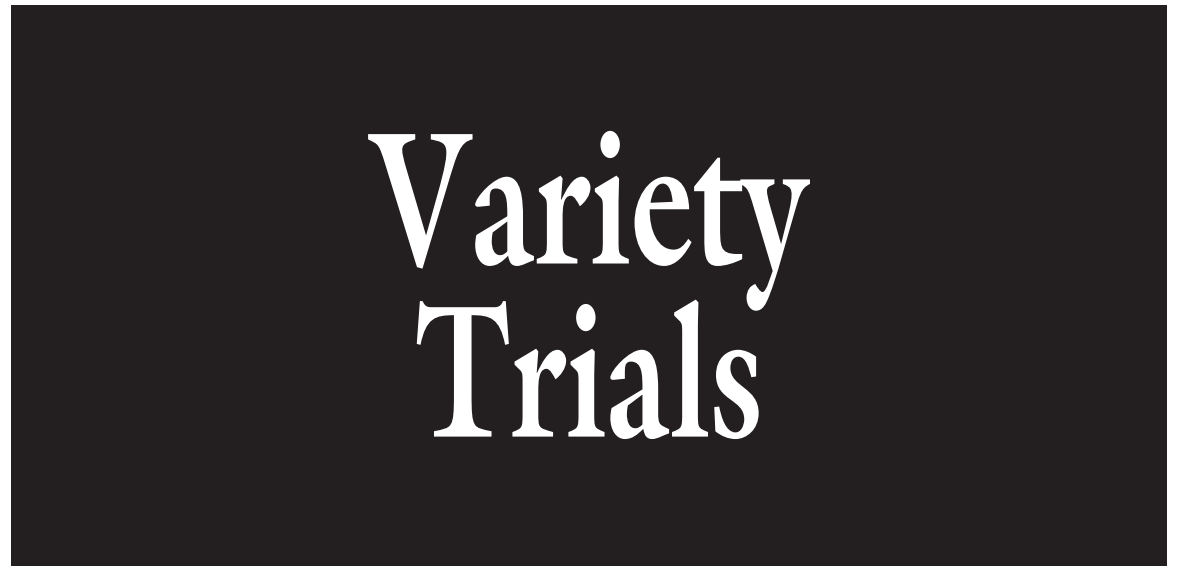

\section{Agronomic and Commercial Performance of Four Spanish Carob Cultivars}

\author{
Joan Tous ${ }^{1}$, Agustí Romero, Juan F. Hermoso, Antònia Ninot, \\ Joan Plana, and Ignasi Batlle
}

AdDITIONAL INDEX WORDs. Ceratonia siliqua, Spain, vigor, precocity, production, pod and kernel characteristics, gum content, galactomannans

SUMMARY. The carob tree (Ceratonia siliqua) shows interesting prospects for some coastal Mediterranean growing areas and is widely used for industrial, agricultural, and ornamental purposes. It can be an alternative crop adapted to part-time farming and can also be used to regenerate vegetation in areas with a mild climate and erosion problems. Four Spanish carob cultivars were examined (Banya de Cabra, Duraio, Matalafera, and Rojal) to determine the one that performed the best for planting new orchards in northeastern Spain (Catalonia). The trees in this rain-fed trial (average rainfall of $500 \mathrm{~mm}$ ) were planted in 1986 using seedling rootstocks that were budded in 1987. The trees were trained using the free-vase system and were spaced $8 \times 9 \mathrm{~m}$ (138 trees/ha including $12 \%$ pollinators). The results showed that 'Rojal' was the earliest bearing cultivar. However, no significant differences were observed for cumulative pod production 18 years after budding. With respect to cumulative seed yield, 'Duraio' had the highest production $(95 \mathrm{~kg} / \mathrm{tree})$. The lowest tree vigor (trunk cross-section) was observed in 'Matalafera'. 'Rojal' trees produced the largest pods (average fruit weight of $18.9 \mathrm{~g}$ ) and lowest seed content (11.8\%), while 'Banya de Cabra' and 'Duraio' produced the smallest fruit (weighing 15.3 and $16.2 \mathrm{~g}$, respectively) with the highest seed content $(15.2 \%$ and $17.3 \%$, respectively). Gum content, expressed as a percentage of the dry weight, was highest in 'Duraio' (56.9\%) and was lowest in 'Rojal' (54.1\%). Thus, in terms of kernel and pod production, 'Duraio' appeared to be the best-performing female cultivar for planting new carob orchards. leguminous tree but is unable to fix atmospheric nitrogen (Martins-Loução and Rodríguez-Barrueco, 1982). Carob beans and seeds are used for many purposes, including food, fodder, and for making industrial products such as gums, sugar, and alcohol (Batlle and Tous, 1997; Calixto and Cañellas, 1982; Winer, 1980). Currently, carob pods are also explored as material for the production of bioethanol (Barracosa et al., 2008). The tree is also used for shade, restoring vegetation, and erosion control (Carlson, 1986; Esbenshade and Wilson, 1986; National Academy of Sciences, 1979). The European Union (namely Spain, Italy, Portugal, Greece, and Cyprus) produces more than $70 \%$ of the world crop, currently estimated to be around $300,000 \mathrm{t}$ of pods, with Spain being the largest producer (accounting for $100,000 \mathrm{t}$ ). The other $30 \%$ is produced mainly in Morocco, Turkey, Algeria, and Tunisia. Until the 1960s, the pulp of the carob pod (90\% of fruit weight) was traditionally used for animal feed. In Europe, the most valued part of the carob pod is currently the seed (about $10 \%$ of fruit weight) for extraction of the gum (additive E-410), which has a galactomannan content of about $80 \%$. Locust bean gum (LBG) is used as a stabilizer and thickening agent in the food industry (Batlle and Tous, 1997; Johnsen et al., 1988; Neukom, 1989; Spina, 1986). In recent decades, this use has fostered interest in carob cultivation (Tous and Ferguson, 1996). Commercial cultivars and wild types differ largely in terms of pulp production, seed yield, and LBG content (Crescimanno et al., 1988; Kalaitzakis et al., 1988; SánchezCapuchino et al., 1988; Tous et al., 2001, 2006). The main cultivars
$\mathrm{T}$ he carob tree is a dioecious species with some hermaphroditic forms. It is a thermophilous evergreen tree that is well adapted to areas with a low altitude in the Mediterranean basin. Carob is a

This research study was partially funded by the INIA (project RFP2004-00011-00-00), by the DURSIAGAUR (2005 SGR 00704), and by DAR institutions.

We thank the owner of the orchard at "Mas Blanquet" for the facilities provided to carry out this work

Institut de Recerca i Tecnologia Agroalimentàries (IRTA), Mas de Bover Crta, Reus-El Morell, km 3,8, E-43120 Constantí, Spain

${ }^{1}$ Corresponding author. E-mail: joan.tous@irta.es.

\begin{tabular}{|c|c|c|c|}
\hline \multicolumn{4}{|l|}{ Units } \\
\hline $\begin{array}{l}\text { To convert U.S. to SI, } \\
\text { multiply by }\end{array}$ & U.S. unit & SI unit & $\begin{array}{l}\text { To convert SI to U.S., } \\
\text { multiply by }\end{array}$ \\
\hline 0.4047 & $\operatorname{acre}(\mathrm{s})$ & ha & 2.4711 \\
\hline 0.3048 & $\mathrm{ft}$ & $\mathrm{m}$ & 3.2808 \\
\hline 0.0283 & $\mathrm{ft}^{3}$ & $\mathrm{~m}^{3}$ & 35.3147 \\
\hline 0.0700 & $\mathrm{ft}^{3} /$ acre & $\mathrm{m}^{3} \cdot \mathrm{ha}^{-1}$ & 14.2913 \\
\hline 2.54 & inch(es) & $\mathrm{cm}$ & 0.3937 \\
\hline 25.4 & inch(es) & $\mathrm{mm}$ & 0.0394 \\
\hline 6.4516 & inch $^{2}$ & $\mathrm{~cm}^{2}$ & 0.1550 \\
\hline 0.4536 & $\mathrm{lb}$ & $\mathrm{kg}$ & 2.2046 \\
\hline 1.1209 & $\mathrm{lb} / \mathrm{acre}$ & $\mathrm{kg} \cdot \mathrm{ha}^{-1}$ & 0.8922 \\
\hline 16.0185 & $\mathrm{lb} / \mathrm{ft}^{3}$ & $\mathrm{~kg} \cdot \mathrm{m}^{-3}$ & 0.0624 \\
\hline 28.3495 & $\mathrm{OZ}$ & $\mathrm{g}$ & 0.0353 \\
\hline 0.9072 & $\operatorname{ton}(\mathrm{s})$ & $\mathrm{t}$ & 1.1023 \\
\hline$\left({ }^{\circ} \mathrm{F}-32\right) \div 1.8$ & ${ }^{\circ} \mathrm{F}$ & ${ }^{\circ} \mathrm{C}$ & $\left(1.8 \times{ }^{\circ} \mathrm{C}\right)+32$ \\
\hline
\end{tabular}


grown in orchards in Spain, and other traditional Mediterranean countries have a high pulp content and low seed yield and are consequently not suitable for the new industrial uses aimed at kernel production (Tous and Batlle, 1990).

Previous studies on carob cultivars have focused on genetic variability (Barracosa et al., 2008; Caruso et al., 2008; Makrem et al., 2006; Tous et al., 1992), fruit description
(Albanell et al., 1996; Barbagallo et al., 1997; Barracosa et al., 2007; Batlle and Tous, 1997; Orphanos and Papaconstantinou, 1969; Russo and Polignano, 1996), and chemical composition (Binder et al., 1959; Caja et al., 1988; Davies et al., 1971; Marakis et al., 1988; Vardar et al., 1980), but there is very little information on the agronomical performance of carob cultivars (Tous and Batlle, 1990), which is why there is

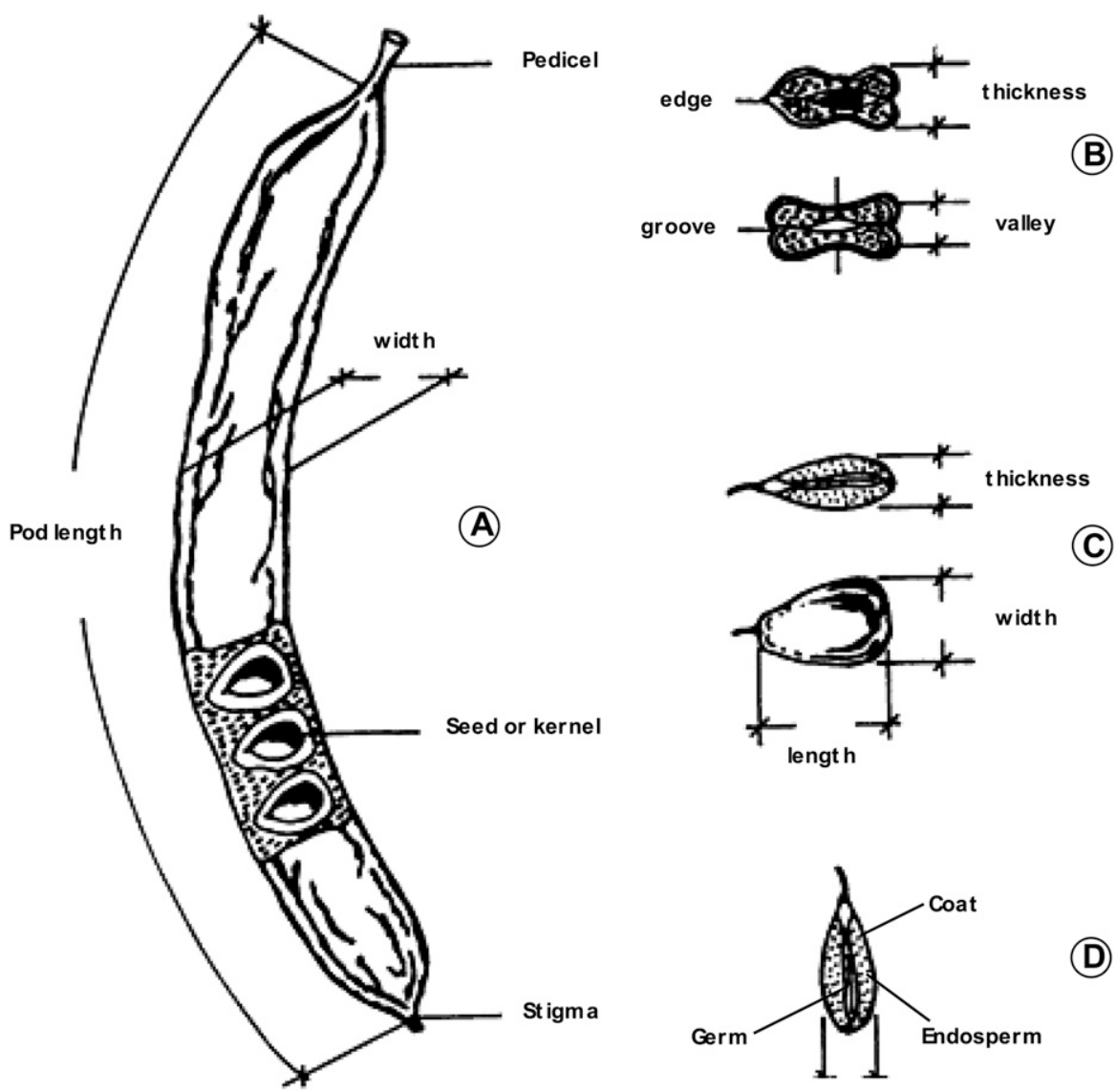

Fig. 1. Carob fruit and seed descriptors used (adapted from Batlle and Tous, 1997): pod (A), cross section of pod (B), kernel (C), and cross-section of seed (D). renewed interest in carob germplasm banks and cultivar trials. Comparative trials are designed to determine which cultivars are best suited to a particular area, but only a few studies have been published (Batlle and Tous, 1998; Coit, 1961, 1967; Tous et al., 2008).

The aim of this carob trial was to determine the performance of four female cultivars growing in a rainfed orchard near the coast of Tarragona (northeastern Spain) to select the most promising cultivar for planting new orchards, especially focusing on seed content and pod production.

\section{Materials and methods}

The trees for the rain-fed carob cultivar trial were planted in 1986 in Perafort, Tarragona, Spain (latitude $41^{\circ} 10^{\prime} \mathrm{N}$, longitude $4^{\circ} 51^{\prime} \mathrm{E}$, altitude $120 \mathrm{~m}$ ). They were trained using the open-vase system and were spaced $8 \times$ $9 \mathrm{~m}$ ( 138 trees/ha). The female carob cultivars used in this trial were Rojal and Banya de Cabra from Catalonia, Duraio from Majorca, and Matalafera from Valencia. They were chosen as they were the main cultivars grown in new orchards in each of these three regions (Batlle and Tous, 1997), and were interplanted with pollinator trees (hermaphrodite and male types) accounting for $12 \%$ of the orchard to provide pollen for female cultivars. The pollinators were planted in every third row and were separated by two female trees within the row. The orchard was located in an area with a Mediterranean coastal climate, high environmental humidity, and average annual rainfall of about $500 \mathrm{~mm}$. The soil was calcareous and basic $(\mathrm{pH} 8)$. The trees were planted as seedling rootstocks and were tied to stakes. The cultivars were T-budded in the following growing season (May 1987)

Table 1. Precocity and yield (1991-2005) of four carob cultivars planted in 1986 (grafted in 1987) in northeastern Spain at $8 \times 9-\mathrm{m}(26.2 \times 29.5 \mathrm{ft})$ spacing [138 trees/ha $(56.2$ trees/acre $)]$.

\begin{tabular}{|c|c|c|c|c|c|c|c|}
\hline \multirow[b]{2}{*}{ Cultivar } & \multirow{2}{*}{$\begin{array}{l}\text { Precocity } \\
(\text { years })^{\mathrm{z}}\end{array}$} & \multirow{2}{*}{$\begin{array}{c}\text { Cumulative early } \\
\text { yield 1991-96 } \\
(\mathrm{kg} / \text { tree })^{\mathrm{y}}\end{array}$} & \multicolumn{2}{|c|}{$\begin{array}{l}\text { Avg yield } \\
\text { 1997-2005 }^{x}\end{array}$} & \multirow{2}{*}{$\begin{array}{c}\text { Alternate bearing } \\
\text { index, } \\
1997-2005^{\mathrm{w}}\end{array}$} & \multicolumn{2}{|c|}{$\begin{array}{c}\text { Cumulative yield } \\
1991-2005\end{array}$} \\
\hline & & & (kg/tree) & $\left(\mathrm{kg} \cdot \mathrm{ha}^{-1}\right)$ & & $\overline{\text { Pods }(\mathrm{kg})^{\mathrm{y}}}$ & Seeds (kg) \\
\hline Banya cabra & 6 & $77.76 b^{v}$ & $52.0 \mathrm{a}$ & $7,176 \mathrm{a}$ & $0.27 \mathrm{a}$ & $545.76 \mathrm{a}$ & $83.0 \mathrm{ab}$ \\
\hline Duraio & 5 & 88.55 b & $51.2 \mathrm{a}$ & 7,065 a & $0.28 \mathrm{a}$ & $549.31 \mathrm{a}$ & $95.0 \mathrm{a}$ \\
\hline Matalafera & 5 & $87.12 \mathrm{~b}$ & $48.4 \mathrm{a}$ & $6,675 a$ & $0.17 \mathrm{a}$ & $522.43 \mathrm{a}$ & $67.4 \mathrm{~b}$ \\
\hline Rojal & 5 & $119.12 \mathrm{a}$ & $57.6 \mathrm{a}$ & $7,953 \mathrm{a}$ & $0.35 \mathrm{a}$ & $637.82 \mathrm{a}$ & $75.3 \mathrm{ab}$ \\
\hline
\end{tabular}

${ }^{\mathrm{z}}$ First year after budding with crop over $1.5 \mathrm{~kg} /$ tree.

$1 \mathrm{~kg}=2.2046 \mathrm{lb}$.

${ }^{x}$ Full yield in years 10 to 18 after budding; $1 \mathrm{~kg} \cdot \mathrm{ha}^{-1}=0.8922 \mathrm{lb} /$ acre

wAlternate bearing index (Pearce and Dobersek-Urbanc, 1967). The alternate-bearing index ranges from 0 to 1 ; a higher index indicates more alternate bearing.

'Means within a column followed by the same letter are not significantly different at $P \leq 0.05$ by Duncan's multiple range test. 
and the source of the budwood was the Spanish Germplasm Bank (Constantí, Spain). Trees were trained to openvase with three to four main branches starting $0.7 \mathrm{~m}$ aboveground. The soil was mechanically disked between rows, and herbicides (glyphosate and oxifluorfen) were applied under tree canopies for weed control.

The statistical design consisted of randomized complete blocks with three replications and five trees per replication and cultivar. From 1991 to 2005 (4-18 years after budding), annual records were taken of the following traits: vigor (cross-sectional area of the trunk $20 \mathrm{~cm}$ above the budding point, and the canopy volume), growth habit (erect, open, or weeping), precocity (first year after budding with a crop of over $1.5 \mathrm{~kg} /$ tree and the first six cumulated crops), annual and cumulative pod production and kernel yield (kilograms per tree), yield efficiency [cumulated pod yield 1997-2005 per unit canopy volume in 2005 (kilograms per cubic meter)], alternate bearing index (Pearce and Dobersek-Urbanc, 1967), ease of harvesting (high, medium, or low), and fruit and seed characteristics.

Pods were harvested from the ground after being knocked down with the help of long bamboo poles and wooden sticks. Carob samples (15 kg per cultivar and block) were taken every year in September from crops in the 1996 to 2003 period. The moisture content of pods at the time of measurement was about $15 \%$ of the fresh weight. Twenty-five pods were randomly sampled from each sample (75 fruits/cultivar). The weight (grams), length (centimeters), width (centimeters), thickness (centimeters), number of seeds, number of aborted seeds, and kernel content (percentage) of each pod were

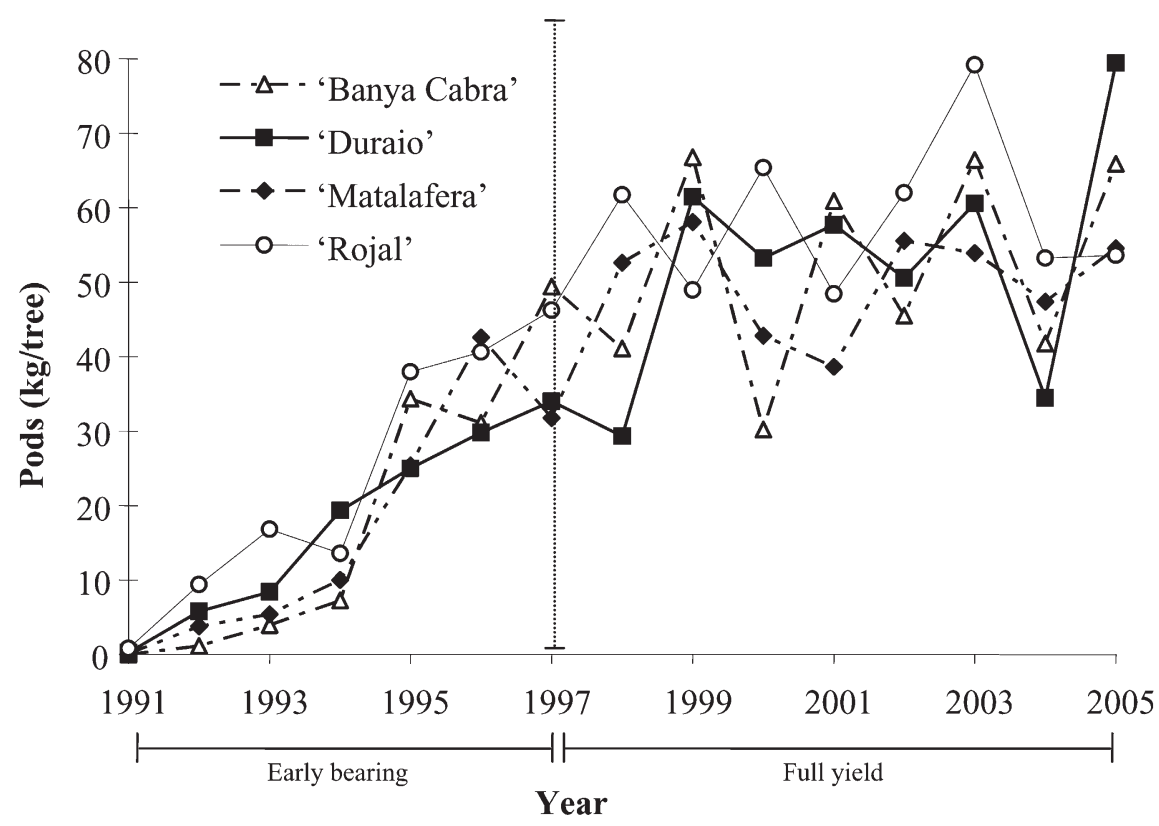

Fig. 2. Annual average yields 1991-2005 for four Spanish carob cultivars planted in 1986 (grafted in 1987). Planting distance was $8 \times 9 \mathrm{~m}(26.2 \times 29.5 \mathrm{ft})$ [138 trees/ ha $(56.2$ trees/acre $)] ; 1 \mathrm{~kg}=2.2046 \mathrm{lb}$. recorded. On samples of 10 seeds per replication (30 seeds/cultivar), weight, length, width, and thickness data were taken (Fig. 1). Seeds were soaked in boiling water for $30 \mathrm{~min}$ and were then divided by hand into the coat, endosperm, and germ. These components were dried in an oven at $105{ }^{\circ} \mathrm{C}$ until a constant weight was reached. The coat, endosperm (LBG), and germ were calculated as percentages of the dry weight. Analysis of variance and Duncan's multiple range test were applied to data for $P \leq 0.05$.

\section{Results and discussion}

YIELD AND GROWTH. The trial showed significant differences in yield characteristics in some data (Table 1). 'Rojal' was an early bearer compared with the other three cultivars. However, 18 years after budding, no significant differences were observed between cultivars in terms of total cumulative pod yield, which ranged from $522 \mathrm{~kg} /$ tree for 'Matalfera' to $638 \mathrm{~kg} /$ tree for 'Rojal'. With respect to cumulated kernel yield, 'Duraio' showed the highest production $(95$ $\mathrm{kg} /$ tree), while the lowest was 'Matalafera' (67 kg/tree). Insignificant differences were observed between cultivars in terms of the alternate bearing index, although 'Rojal' was a more irregular bearer (Table 1 and Fig. 2). Productions recorded in mature trees (equivalent to $7000-8000 \mathrm{~kg} \cdot \mathrm{ha}^{-1}$ in a 150-tree/ha orchard) were similar to those reported by Goor et al. (1958) in Israel $\left(7000 \mathrm{~kg} \cdot \mathrm{ha}^{-1}\right.$ in nonirrigated groves with over $550 \mathrm{~mm}$ of rainfall) and Tous et al. (2008) in northeastern Spain (6783 kg.ha ${ }^{-1}$ for 'Aida') and both were higher than the average productions of traditional orchards, 2000-3000 kg.ha ${ }^{-1}$ with 50 trees/ha (Tous and Batlle, 1990).

The smallest trunk cross-section was observed in 'Matalafera' (Table 2

Table 2. Vegetative and productive characteristics of four carob cultivars, 19 years old (18th year after budding) in northeastern Spain. Mean values from 1991 to 2005.

\begin{tabular}{|c|c|c|c|c|c|c|}
\hline \multirow[b]{2}{*}{ Cultivar } & \multirow{2}{*}{$\begin{array}{c}\text { Cumulative yield, } \\
\text { 1997-2005 }(\mathrm{kg} / \text { tree })^{\mathrm{z}}\end{array}$} & \multirow{2}{*}{$\begin{array}{c}\text { Trunk cross } \\
\text { section } 2005\left(\mathrm{~cm}^{2}\right)^{\mathrm{z}}\end{array}$} & \multicolumn{2}{|c|}{ Canopy volume 2005} & \multirow{2}{*}{$\begin{array}{l}\text { Cumulative yield } \\
\text { efficiency }\left(\mathrm{kg} \cdot \mathrm{m}^{-3}\right)^{\mathrm{y}}\end{array}$} & \multirow{2}{*}{$\begin{array}{c}2005 \mathrm{yield} \\
\text { efficiency }\left(\mathrm{kg} \cdot \mathrm{m}^{-3}\right)\end{array}$} \\
\hline & & & $\left(\mathrm{m}^{3} / \text { tree }\right)^{\mathrm{z}}$ & $\left(\mathrm{m}^{3} \cdot \mathrm{ha}^{-1}\right)^{\mathrm{z}}$ & & \\
\hline Banya cabra & $468.00 \mathrm{a}^{\mathrm{x}}$ & $871 \mathrm{a}$ & $153.29 \mathrm{a}$ & $21,154 \mathrm{a}$ & $3.05 \mathrm{~b}$ & $0.429 \mathrm{a}$ \\
\hline Matalafera & $435.31 \mathrm{a}$ & $612 \mathrm{~b}$ & $117.93 \mathrm{a}$ & $16,274 \mathrm{a}$ & $3.77 \mathrm{a}$ & $0.479 \mathrm{a}$ \\
\hline Rojal & $518.70 \mathrm{a}$ & $737 \mathrm{ab}$ & $152.83 \mathrm{a}$ & $21,090 \mathrm{a}$ & $3.40 \mathrm{ab}$ & $0.339 \mathrm{a}$ \\
\hline
\end{tabular}

${ }^{\mathrm{z}} \mathrm{l} \mathrm{kg}=2.2046 \mathrm{lb}, \mathrm{l} \mathrm{cm}{ }^{2}=0.1550 \mathrm{in}^{2}, \mathrm{l} \mathrm{m}^{3}=35.3147 \mathrm{ft}^{3}, \mathrm{l} \mathrm{m}^{3} \cdot \mathrm{ha}^{-1}=14.2913 \mathrm{ft}^{3} /$ acre.

yCumulative yield 1997 to 2005 per unit tree canopy volume in 2005 when carob tree size is quite stabilized; $1 \mathrm{~kg} \cdot \mathrm{m}^{-3}=0.0624 \mathrm{lb} / \mathrm{ft}^{3}$.

${ }^{x}$ Means within a column followed by the same letter are not significantly different at $P \leq 0.05$ by Duncan's multiple range test. 
and Fig. 3) 19 years after plantation, while canopy volumes of full-bearing trees showed no significant differences between cultivars, and ranged from $16,274 \mathrm{~m}^{3} \cdot \mathrm{ha}^{-1} \quad$ ('Matalfera') to 21,154 $\mathrm{m}^{3} \cdot \mathrm{ha}^{-1}$ ('Banya de Cabra'). To determine the balance between the productive and vegetative performance of the four cultivars, "cumulative yield efficiency" was evaluated during the full yield phase (Table 2). The highest index score was observed in 'Matalfera' $\left(3.7 \mathrm{~kg} \cdot \mathrm{m}^{-3}\right)$ and the lowest in 'Banya de Cabra' $\left(3.05 \mathrm{~kg} \cdot \mathrm{m}^{-3}\right)$.

Cultivar CHaracteristics RELATED TO THE HARVEST EFFICIENCY. The main costs of carob production come from harvesting, which represents about $30 \%$ to $35 \%$ of total crop value (Tous and Batlle, 1990). Many cultivar traits (growth habit, fruit ripening and abscission, size and pod shape, pedicel length, etc.) can influence the ease of harvest, which is usually carried out by knocking the pod off with long thin poles (traditional orchards) or by mechanical shaking using trunk and branch shakers and/or sweepers and pickers (new orchards). In this trial, three types of growth habits were observed: erect ('Rojal'), semierect ('Banya de Cabra'), and open ('Matalafera' and 'Duraio'). Another interesting trait observed was the difference in fruit ripening and natural fruit drop. 'Matalafera' showed earlier ripening (at the end of August), while other cultivars ripened 1 month later. 'Matalafera', with shorter pedicels, also displayed easier pod abscission than the other three cultivars. The main consideration should be to choose cultivars in which the pods all ripen and fall at the same time, as the 'Matalafera', to make collection from the ground easier (Batlle and Tous, 1997).

Fruit characteristics. 'Rojal' and 'Matalafera' trees produced the largest pods (average fruit weight of 18.9 and $18.4 \mathrm{~g}$, respectively) with the lowest seed content $(11.8 \%$ and $12.9 \%$,

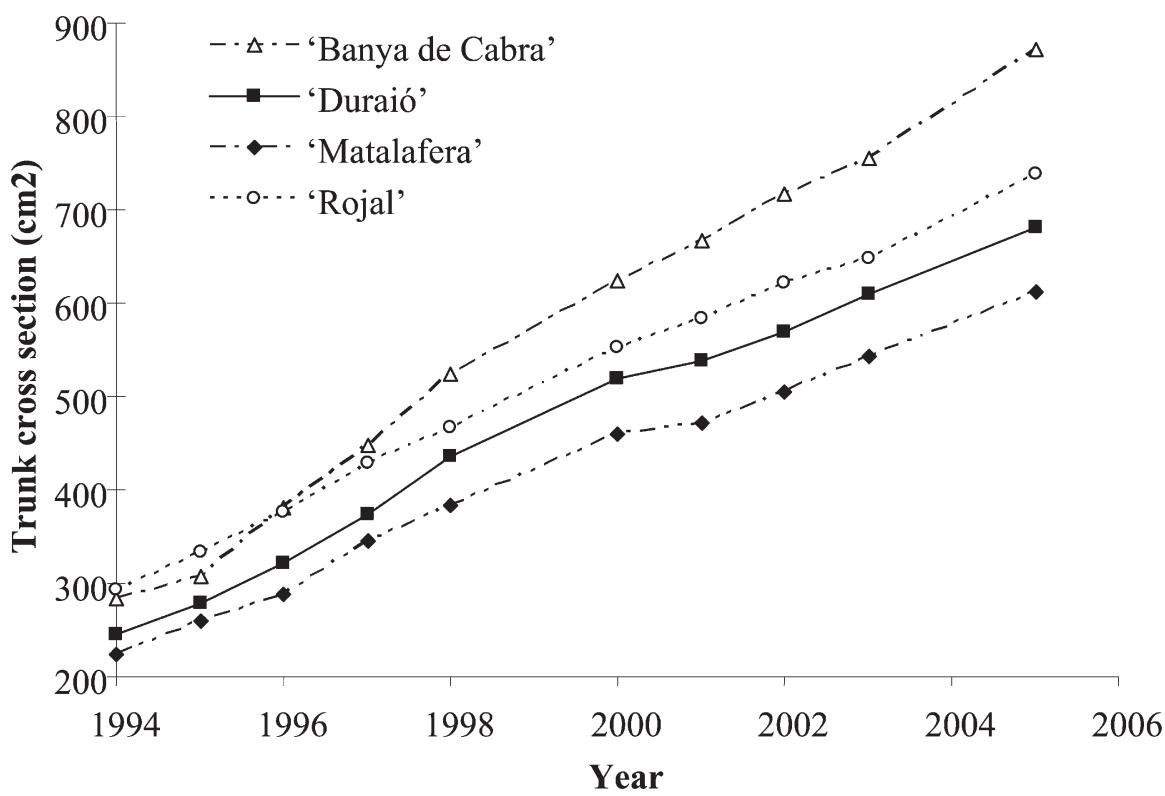

Fig. 3. Trunk cross-section evolution of for four Spanish carob cultivars during 1994-2005 (7-18 years after budding); $1 \mathrm{~cm}^{2}=0.1550 \mathrm{in}^{2}$. respectively), while 'Banya de Cabra' and 'Duraio' produced the smallest fruit (15.3 and $16.2 \mathrm{~g}$, respectively) with the highest seed content (15.2\% and $17.3 \%$, respectively) (Table 3 ). The seed yield of 'Duraio' pods was more variable than the other cultivars, and ranged from $15 \%$ to $18 \%$, depending on crop load and environmental conditions (data not shown). Cultivars with large pods (high pulp content) usually showed lower seed yield $(r=$ $-0.79)$. These results agreed with those of Albanell et al. (1996) and Barracosa et al. (2007), who showed that to achieve high seed yield, it is important to select thin, narrow carobs with pods that are not too heavy and have a large number of seeds. The main Mediterranean carob cultivars have a high pulp content and a low seed yield, ranging from $7 \%$ to $16 \%$ (Crescimanno et al., 1988; Marakis et al., 1988; Melgarejo and Salazar,

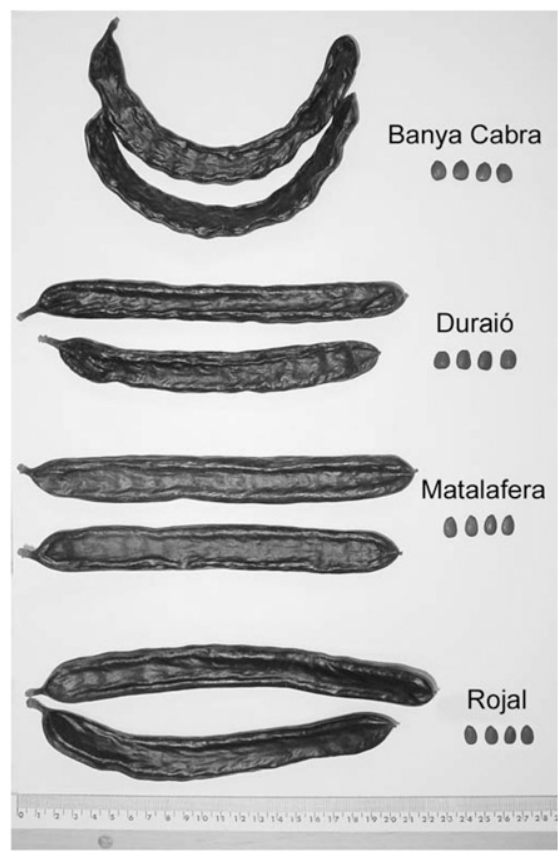

Fig. 4. Fruit and kernel samples of four Spanish carob cultivars.

Table 3. Pod characteristics of four carob cultivars in northeastern Spain. Average from 1996 to $2003 .^{\mathrm{z}}$

\begin{tabular}{|c|c|c|c|c|c|c|c|}
\hline Cultivar & $\mathrm{Wt}(\mathrm{g})^{\mathrm{y}}$ & Length $(\mathrm{cm})^{\mathrm{y}}$ & Width $(\mathrm{cm})$ & Thickness $(\mathrm{cm})$ & Seed (no.) & $\begin{array}{c}\text { Aborted seeds } \\
\text { (no.) }\end{array}$ & $\begin{array}{c}\text { Kernel content } \\
(\%)\end{array}$ \\
\hline Banya de cabra & $15.34 c^{x}$ & $17.50 \mathrm{a}$ & $1.94 \mathrm{c}$ & $0.76 \mathrm{c}$ & $11.0 \mathrm{~b}$ & $1.8 \mathrm{a}$ & $15.2 \mathrm{~b}$ \\
\hline Duraio & $16.26 \mathrm{~b}$ & $15.99 \mathrm{~b}$ & $1.85 \mathrm{~d}$ & $0.89 \mathrm{~b}$ & $12.3 \mathrm{a}$ & $1.0 \mathrm{~b}$ & $17.3 \mathrm{a}$ \\
\hline Matalafera & $18.45 \mathrm{a}$ & $16.04 \mathrm{~b}$ & $2.17 \mathrm{a}$ & $1.00 \mathrm{a}$ & $12.3 \mathrm{a}$ & $2.0 \mathrm{a}$ & $12.9 \mathrm{c}$ \\
\hline Rojal & $18.99 \mathrm{a}$ & $17.55 \mathrm{a}$ & $2.03 \mathrm{~b}$ & $0.88 \mathrm{~b}$ & $12.5 \mathrm{a}$ & $2.1 \mathrm{a}$ & $11.8 \mathrm{~d}$ \\
\hline
\end{tabular}

${ }^{2}$ Each value in the table represents and average of 8 years of data with three blocks (replication) per cultivar and 25 fruits/cultivar and replication

${ }^{\mathrm{y}} \mathrm{l} \mathrm{g}=0.0353 \mathrm{oz}, \mathrm{l} \mathrm{cm}=0.3937$ inch.

${ }^{x}$ Means within a column followed by the same letter are not significantly different at $P \leq 0.05$ by Duncan's multiple range test. 
Table 4. Seed characteristics of four carob cultivars in northeastern Spain. Average from 1996 to $2003 .^{z}$

\begin{tabular}{llcccccc}
\hline Cultivar & Wt $(\mathrm{g})^{\mathrm{y}}$ & Length $(\mathrm{cm})^{\mathrm{y}}$ & Width $(\mathrm{cm})$ & Thickness $(\mathrm{cm})$ & Coat $(\%)$ & Endosperm $^{\mathrm{x}}(\%)$ & Germ $(\%)^{(\%)}$ \\
\hline Banya cabra & $0.22 \mathrm{~b}^{\mathrm{w}}$ & $0.98 \mathrm{~b}$ & $0.79 \mathrm{a}$ & $0.391 \mathrm{~b}$ & $20.7 \mathrm{c}$ & $56.3 \mathrm{a}$ & $22.0 \mathrm{a}$ \\
Duraio & $0.24 \mathrm{a}$ & $0.93 \mathrm{c}$ & $0.77 \mathrm{~b}$ & $0.446 \mathrm{a}$ & $21.3 \mathrm{c}$ & $56.9 \mathrm{a}$ & $20.2 \mathrm{c}$ \\
Matalafera & $0.20 \mathrm{c}$ & $1.04 \mathrm{a}$ & $0.68 \mathrm{c}$ & $0.382 \mathrm{c}$ & $22.4 \mathrm{~b}$ & $54.3 \mathrm{~b}$ & $21.6 \mathrm{ab}$ \\
Rojal & $0.19 \mathrm{~d}$ & $0.97 \mathrm{~b}$ & $0.66 \mathrm{~d}$ & $0.387 \mathrm{bc}$ & $24.0 \mathrm{a}$ & $54.1 \mathrm{~b}$ & $20.6 \mathrm{bc}$
\end{tabular}

${ }^{2}$ Each value in the table represents an average of 8 years of data with three blocks (replication) per cultivar and 10 seeds/cultivar and replication.

${ }^{\mathrm{y}} \mathrm{l} \mathrm{g}=0.0353 \mathrm{oz}, \mathrm{l} \mathrm{cm}=0.3937$ inch.

${ }^{x}$ Locust bean gum (LBG) content.

"Means within a column followed by the same letter are not significantly different at $P \leq 0.05$ by Duncan's multiple range test.

2003; Tous et al., 2001). Currently, a commercial cultivar will be considered if average seed yield is minimum $15 \%$. Regarding pod size and shape (Fig. 4), 'Rojal' and 'Banya de Cabra' had the longest pods, while 'Banya de Cabra' was the only cultivar that produced bent fruit. 'Banya de Cabra' pods also had the lowest number of seeds and 'Duraio' fruit had the lowest number of aborted seeds.

Seed Characteristics. 'Duraio' trees produced the largest seeds $(0.24 \mathrm{~g}$ on average), while 'Rojal' produced the smallest seeds $(0.19 \mathrm{~g})$ (Table 4$)$. To consider a cultivar as medium quality for industry applications, about $0.2 \mathrm{~g}$ of seed weight is the required minimum. In other works, the average individual seed weight ranged from 0.12 to $0.26 \mathrm{~g}$ (Albanell et al., 1996; Barracosa et al., 2008; El Ferchichi et al., 2008; Tous et al., 2008). The highest LBG content in carob trees is generally found in thick, heavy, short carob seeds (Albanell et al., 1996). Kernel thickness was significantly higher in 'Duraio' (0.44), followed by 'Banya de Cabra' and 'Rojal' (about 0.39), and the lowest in 'Matalafera' (0.38). LBG content, expressed as a percentage of the dry weight, was the highest in 'Duraio' (56.9\%) and 'Banya de Cabra' (56.3\%), and was the lowest in 'Rojal' (54.1\%). In previous studies of carob cultivars, the average endosperm (LBG) content ranged from $31 \%$ to $60 \%$ (Albanell et al., 1996; Barbagallo et al., 1997; Batlle and Tous, 1997).

\section{Conclusions}

In the 19 years of this comparative carob cultivar trial, significant differences were observed in some data on yield and fruit characteristics. 'Rojal' showed early bearing in relation to the other three cultivars. Average pod production per tree (10-18 years after budding) did not show significant differences between cultivars. 'Matalafera' presents the easiest pod abscission, because of its shorter pedicels. With respect to cumulated seed yield, 'Duraio' produced the largest yields and was statistically significant. Regarding fruit and seed quality, 'Duraio' pods were of medium size with higher seed yield and the highest LBG content. When comparing the four Spanish female cultivars tested, 'Duraio' seemed to be the best-performing cultivar for planting new carob orchards under similar environmental conditions.

\section{Literature cited}

Albanell, E., G. Caja, and J. Plaixats. 1996. Characterization of carob fruits (Ceratonia siliqua L.) cultivated in Spain for agroindustrial use. Intl. Tree Crops J. 9:1-9.

Barbagallo, M.G., R. di Lorenzo, R. Meli, and F.G. Crescimanno. 1997. Characterization of carob germplasm (Ceratonia siliqua L.) in Sicily. J. Hort. Sci. 72:537-543.

Barracosa, P., J. Osorio, and A. Cravador. 2007. Evaluation of fruit and seed diversity and characterization of carob (Ceratonia siliqua L.) cultivars in Algarve region. Scientia Hort. 114:250-257.

Barracosa, P., M.B. Lima, and A. Cravador. 2008. Analysis of genetic diversity in Portuguese Ceratonia siliqua L. cultivars using RAPD and AFLP markers. Scientia Hort. 118:189-199.

Batlle, I. and J. Tous. 1997. The carob (Ceratonia siliqua L.). Promoting the conservation and use of underutilized and neglected crops. 17. Inst. Plant Genet. Crop Plant Res., Gatersleben/Intl. Plant Genet. Resources Inst. (IPGRI), Rome.

Batlle, I. and J. Tous. 1998. Rojal carob. Fruit Var. J. 52:51-52.

Binder, R.J., J.E. Coit, K.T. Williams, and J.E. Brekke. 1959. Carob varieties and composition. Food Technol. 13:213-216.

Caja, G., E. Albanell, and R. Casanova. 1988. Composición química en principios inmediatos de la pulpa de garrofas españolas, p. 131-136. Proc. II Intl. Carob Symp., Valencia, Spain.
Calixto, F.S. and J. Cañellas. 1982. Components of nutritional interest in carob pods (Ceratonia siliqua). J. Sci. Food Agr. 33:1319-1323.

Carlson, W.A. 1986. The carob: Evaluation of trees, pods and kernels. Intl. Tree Crops J. 3:281-290.

Caruso, M., S. La Malfa, T. Pavlicek, D. Frutos, A. Gentile, and E. Tribulato. 2008. Characterization and assessment of genetic diversity in cultivated and wild carob (Ceratonia siliqua L.) genotypes using AFLP markers. J. Hort. Sci. Biotechnol. 83:177-182.

Crescimanno, F.G., A. De Michelle, R. di Lorenzo, G. Occorso, and A. Raimondo. 1988. Aspetti morfologici e carpologici di cultivar di carrubo (Ceratonia siliqua), p. 169-181. Proc. II Intl. Carob Symp., Valencia, Spain.

Coit, J.E. 1961. Carob varieties. Fruit Var. Hort. Dig. 15:75-77.

Coit, J.E. 1967. Carob varieties for the semiarid southwest. Fruit Var. Hort. Dig. 21:5-9.

Davies, W.N., P.I. Orphanos, and J. Papaconstantinou. 1971. Chemical composition of developing carob pods. J. Sci. Food Agr. 22:83-86.

El Ferchichi, H., S. Naghmouchi, D.J. Walker, E. Correal, M. Boussaid, and M.L. Khouja. 2008. Variability in the pod and seed parameters and nuclear DNA content of Tunisian populations of Ceratonia siliqua L. Agrofor. Syst. 74:73-81.

Esbenshade, H. and G. Wilson. 1986. Growing carobs in Australia. Goddard and Dobson, Victoria, Australia.

Goor, A.Y., R.J. Ticho, and Y.G. Garmi. 1958. The carob. Agr. Publ. Section. Ministry Agr., Tel Aviv, Israel (in Hebrew with English summary).

Johnsen, S., P. Bruun, and P. Okkala. 1988. Application of LBG in food and pet food systems, p. 577-587. Proc. II Intl. Carob Symp., Valencia, Spain.

Kalaitzakis, J.K., K. Mitrakos, and S. Marakis. 1988. Carob tree varieties from Crete (Greece), p. 291-301. Proc. II Intl. Carob Symp., Valencia, Spain. 
Makrem, A., N. Ben Fadhel, M.L. Khoudja, and M. Boussaid. 2006. Genetic diversity in Tunisian Ceratonia siliqua (Caesalpinioideae) natural populations. Genet. Resources Crop Evol. 53:1501-1511.

Marakis, S., J.K. Kalaitzakis, and K. Mitrakos. 1988. Criteria for recognizing carob tree varieties, p. 558-566. Proc. II Intl. Carob Symp., Valencia, Spain.

Martins-Loução, M.A. and C. RodríguezBarrueco. 1982. Studies in nitrogenase activity of carob (Ceratonia siliqua L.) callus cultures associated with Rhizobium, p. 671-672. Proc. V Intl. Congress Plant Tissue Culture, Tokyo.

Melgarejo, P. and D.M. Salazar. 2003. Tratado de fruticultura para zonas áridas y semiáridas (Vol. II): Algarrobo, granado y jinjolero. A. Madrid Vicente and MundiPrensa, Madrid, Spain.

National Academy of Sciences. 1979. Carob, p. 109-1 16. In: Tropical legumes: Resources for the future. National Academy of Sciences, Washington, DC.

Neukom, H. 1989. Galactomannans: Properties and applications. LebensmittelWissenschaft und Technologie 22:41-45.
Orphanos, P.I. and J. Papaconstantinou. 1969. The carob varieties of Cyprus. Tech. Bul. 5. Cyprus Agricultural Research Institute. Nicosia, Cyprus.

Pearce, S.C. and S. Dobersek-Urbanc. 1967. The management of irregularity in growth and cropping. J. Hort. Sci. 42:295-305.

Russo, G. and G.B. Polignano. 1996. Variation of seed and fruit characters in Ceratonia siliqua L. cultivars. Genet. Resources Crop Evol. 43:525-531.

Sánchez-Capuchino, J.A., D. Salazar, S. García, R. Martínez, and P. Melgarejo. 1988. Tipificación morfológica de los algarrobos de la Comunidad Valenciana, p. 69-78. Proc. II Intl. Carob Symp., Valencia, Spain

Spina, P. 1986. Il carrubo. Edagricole, Bologna, Italy.

Tous, J. and I. Batlle. 1990. El algarrobo. Mundi-Prensa, Madrid, Spain.

Tous, J. and L. Ferguson. 1996. Mediterranean fruits, p. 416-430. In: J. Janick (ed.). Progress in new crops. ASHS Press, Alexandria, VA.
Tous, J., A. Romero, J.F. Hermoso, A. Ninot, and J. Plana. 2008. Fruiting and kernel production characteristics of ten Mediterranean carob cultivars in northeastern Spain. J. Amer. Pomol. Soc. 62:144-150.

Tous, J., C. Olarte, M.J. Truco, and P. Arús. 1992. Isozyme polymorphisms in carob cultivars. HortScience 27:257-258.

Tous, J., I. Batlle, J. Rallo, and A. Romero. 2001. Prospección de variedades de algarrobo en las islas Baleares. Investigación Agraria: Producción i Protección Vegetal 16:187-203.

Tous, J., M. Rovira, A. Romero, A. Makrem, M.L. Khouja, and M. Boussaid. 2006. Carob tree germplasm in Tunisia. Nucis Nwsl. 13:55-59.

Vardar, Y., Ö. Seçmen, and M. Öztürk. 1980. Some distributional problems and biological characteristics of Ceratonia in Turkey. Portugaliae Acta Biologica (A) 16(1-4):75-86.

Winer, N. 1980. The potential for the carob. International Tree Crops J. 1:15-26. 